\title{
An Implementation of Sustainability Reporting Model in Village-Owned Enterprise and Small and Medium Enterprise: Case Study in Bali, Indonesia
}

\author{
Putu Sukma Kurniawan* \\ Department of Accounting, Faculty of Economics, Universitas Pendidikan Ganesha \\ putusukma1989@gmail.com
}

\begin{abstract}
Sustainability reporting becomes a new paradigm in corporate reporting. This article discusses the implementation of sustainability reporting model on village-owned enterprise (VOE) and small and medium enterprises (SMEs), especially in Indonesia. This research design is a qualitative descriptive study and literature research. This research was conducted at the village-owned enterprise and some small and medium enterprise in Tajun village, Buleleng, Bali. The process of this research divided into initial research, data collection, create the sustainability reporting model, and the implementation of the sustainability reporting model. The methods of collected data are semi-structured interview, observation, and document analysis. Sustainability reporting model in village-owned enterprise and small and medium enterprises based on GRI G4 standard. There are five stages on sustainability reporting model for VOE and SMEs. The five stages are prepare stage, connect stage, define stage, monitoring stage, and reporting stage. Sustainability reporting on VOE and SMEs increases transparency towards stakeholders and improves the optimization of business process. This result indicated that VOE and SMEs can more contribute than other related business in sustainability context. Keywords: sustainability reporting, sustainability reporting model, village-owned enterprise, small and medium enterprises
\end{abstract}

\section{Introduction}

Sustainability reporting becomes new paradigm in corporate reporting. Delivering information with sustainability report platform shows that the company's management has a high commitment to run the company's business in the concept of sustainability. The concept of sustainability has a sense that all business activities are not only thinking of stakeholders in the company, but also to think about the impact of the company's business to stakeholders outside the company. Medel et al. (2011) argue that corporate sustainability help our companies create long terms consumers and employee value and consider of how business operates in the social and environmental context. All types of industries can deliver information to their stakeholders through sustainability reports. In some companies with a bigger size, delivering information in a sustainability report is a must due to many factors, for example, to maintain the legitimacy of the company and establish communication with the company's stakeholders. Sustainability concept has become an important strategic for keep a dynamic balance of the organization's economic, social, and environmental performance (Medel et al., 2011). Borga et al. (2009) argue that it is important to assess the social and environmental impacts caused by business activities. Sustainability reporting also generates economic value for company. Company's management should concern that economic value help their companies to produce

* Corresponding author. Putu Sukma Kurniawan is a Lecturer at the Faculty of Economics, Universitas Pendidikan Ganesha, Indonesia, e-mail: putusukma1989@gmail.com 
social and environmental benefits. This benefits is not only for company's (management, employee, and shareholders) but also for all company's stakeholders. GRI and IOE (2014) argue that there is a trend for stock exchange and other regulators to translate the business goals into laws, regulations, and requirements for sustainability and reporting on non-financial data, such as: (1) The Johannesburg Stock Exchange (JSE) Listing Requirement (2010) requires 450 South African companies listed on the JSE to generates an annual integrated report (financial and sustainability information) or explain why they do not and (2) The Securities and Exchange Board of India (SEBI) Business Responsibility Reports (2015) initially requires the country's top 500 companies to engage in a through environmental and social reporting process. Medel et al. (2011) argue that reporting is a good way to communicate openly with the stakeholders about company's values, principles, and performance and also build trust. According to a 2008 KMPG survey, approximately $80 \%$ of the world's largest 250 corporations engage in some form of sustainability reporting (Medel et al., (2011).

Discussion on the sustainability report will continue to grow in line with the changing business paradigm from traditional paradigm into the concept of responsible business. Responsible business can mean that the company's management seeks to minimize the social and environmental impact of business activities. Sustainability report contains social and environmental information and also the impacts of communities. Borga et al. (2009) found the change or the latest evolution in the economic and social context has led to the company's management to consider and assess the social and environmental impacts of corporate activity. Lawrence et al. (2006) argue that the literature on sustainable business practices mostly concentrated on multi-national companies, however small and medium-sized enterprises have relatively minor importance individually and if we see this fact wisely, we know that the impacts of SMEs business may be great.

In Indonesia Government Regulation Number 72 (2005) about the Village explained that the village is a community unit that has territorial boundaries with the authority to regulate and have power for local communities, based on the origin and local customs that recognized and respected by the government administration system of the Republic of Indonesia. Based on this understanding, the village authorities to regulate and manage the interests of the local community in order to improve the welfare of the people in the village. In an effort to improve the welfare of the community, the village has the right to explore the potential of the village and develop it into a business entity. The business entity may be established by the village is the village-owned enterprises (BUMDes) or VOE. BUMDes or VOE is a pillar of economic in the village that serves as a social activity (social institution) and commercial activity (commercial institution). As a social institution, BUMDes is operative institution. This term mean BUMDes or VOE is institution that collects the patterns or ways that required the relevant community. Meanwhile, as a commercial institution, BUMDes has effort to produce profits based on their business activity. BUMDes presence is expected to improve the rural economy to be more passionate and more productive so as to increase the income of local communities.

The existence of BUMDes (VOE) and SMEs as the village business entity cannot be separated from all related impact caused by their business activity, one of which impact on the social and environment. Today, the village business entity, likes VOE and SMEs, also need to pay serious attention to the social community and environment in which it operates. The growing activities of the company (VOE and SMEs) to generate profits produces a 
consequences or impact for their social community (stakeholders) and environment. Based on this fact, VOE and SMEs management is not only concern with the impact caused by their business, but also should maintain the relationship with their stakeholders. GRI and IOE (2014) argue that SMEs as the backbone of national economies and the global supply chains of large companies. According to the World Bank, SMEs contribute significantly to GDP and also play a crucial role in creating employment and the another fact is SMEs contribute up to $45 \%$ of total employment and up to 33\% of GDP in emerging economies (GRI and IOE, 2014). ACCA (2010) argue that SMEs represent more than $90 \%$ of global business, on average for about $50 \%$ of GDP of all countries and for $63 \%$ of their employment. Based on this fact, it's clearly to say that SMEs (and also VOE) have a crucial role to play real action in a sustainability ways through responsible business practices and disclose sustainability report.

Sustainability report increase the relationship between VOE and SMEs with their stakeholders. The process of sustainability reporting also help the VOE and SMEs management to concern about social and environmental impacts of their business. Our VOE and SMEs grows up continuously each year and this is the big chance to adopted sustainability reporting and corporate social responsibility in their business. Kocmanova et al. (2011) focus the discussion on economic performance, social performance and environmental performance at the business continuity of SMEs in the Czech Republic. Kocmanova et al. (2011) concluded that economic performance, social performance and environmental performance developed by SMEs can have a big impact on the SMEs business continuity. European Commission (2001) conclude their report that the purpose of future research in CSR is to provide SMEs with guidance to implement and report on their corporate social responsibility policies in an effective manner. The CSR concept is generic and applicable to organizations regardless of their type and size - from public to private and from small and medium enterprises to multinational enterprises (Castka et al., 2004).

Sustainability reporting is important to increase our VOE and SMEs reputation and improve their internal business process. The process of sustainability reporting also improve the capability of VOE and SMEs in the transparency and accountability issues. Transparency and accountability about the organizations activities, especially in VOE and SMEs, is of great interest for a range of stakeholders (Medel, et al., 2011). Sustainability reporting have an important role from the stakeholder's perspectives. Sustainability report help stakeholder's to understand VOE and SMEs more comprehensive than before. This new paradigm of reporting changes the decision making process from VOE and SMEs stakeholder's. Stakeholder's needs all comprehensive information about the VOE and SMEs business activity. The strong relationship between VOE and SMEs with their stakeholder's can bring this relations into the "social capital". Battaglia et al. (2010) says that social capital are the key element to facilitate the CSR policies and practices for small companies business (SMEs). The disclose process about CSR information in SMEs should be based on the concept of social capital (Perrini, 2006). Integrating the practices of CSR and disclose the information in sustainability reporting is crucial and important for SMEs business (Jenkins, 2008). The VOE and SMEs management should maintain the "dialogue" with their stakeholders according to the information on their sustainability report.

It should be realized that the complexity of the VOE and SMEs business is not as high as the companies listed on the capital market so that we can argue that VOE and SMEs do not * Corresponding author. Putu Sukma Kurniawan is a Lecturer at the Faculty of Economics, Universitas Pendidikan Ganesha, Indonesia, e-mail: putusukma1989@gmail.com 
have to disclose information on the sustainability report. Against this concept, if we want the concept of responsible business can be carried out properly, it should have all parties (include VOE and SMEs) in a business environment running a responsible business concepts. Villageowned enterprises and small and medium enterprises is one of the component in a business environment, so VOE and SMEs should also be able to do business responsibly. ACCA (2010) argue that SMEs with sustainability integrated in their business models have a big access to new markets and increased business opportunities. Johnson and Schaltegger (2015) argue that SMEs should implement sustainability management tools to improve the quality of their business.

Through this article, the author tries to discuss how the implementation model of sustainability reporting process on village-owned enterprise (VOE) and small and medium enterprises (SMEs). This paper also create a sustainability reporting model for VOE and SMEs business. This paper contain two parts. The first part is explain about creating a sustainability reporting model for VOE and SMEs business and the second part tell about the implementation of the sustainability reporting model on VOE and SMEs. Medel et al. (2011) provides some general ideas to integrate corporate sustainability frameworks into VOE and SMEs business, (1) think that sustainability strategy analysis is the first step of the integration and the strategy should cover the organizations good performance commitments. Also promote the stakeholder's dialogue thorough the feedback, (2) it's important to clarify the main objectives, critical success factors and the main interest topics of stakeholders, and (3) sustainability indicators as a key of evaluation process. This study uses the concept of general idea from Medel et al. (2011) as a reference to implement the sustainability reporting model. This study focuses on how the implementation of a model of sustainability reporting at VOE and SMEs. The first phase of this study was to develop a model of sustainability reporting for VOE and SMEs. The next stage is the implementation of sustainability reporting model on the object of research.

\section{Literature Review}

\section{Sustainability Reporting Framework and GRI G4}

Sustainability reporting is about disclosing your organization's most significant impacts (GRI and IOE, 2014). A sustainability report should encompass organization's values and governance model and also link the business performance to a sustainable global economy. Sustainability report help management to delivery of comprehensive information from company management to the company's stakeholders. Comprehensive information can divided into financial information and non-financial information. Company's stakeholders need all comprehensive information from company's management in the context of decision making process. In the GRI G4 standard contains two types of standard disclosures, ie general disclosures and specific disclosures (NCSR, 2017). General disclosure such as the strategy and firm analysis, company profiles, identification of material aspects for the company, relationships with stakeholders, the report profiles, and corporate governance. While specific disclosures include disclosures regarding economic performance, environmental performance and social performance. Examples of disclosure of economic performance, such as the direct 
economic benefit received by stakeholders and the company's economic performance. Disclosure of social performance is divided into four sections, namely disclosure about labor, human rights, social communities, and responsibility for the product. Disclosure of environmental performance include energy efficiency, water use, and waste management.

\section{Value of Sustainability Reporting for VOE and SMEs}

VOE and SMEs management are effort or encouraged to start reporting the sustainability concepts to show what their business is about, how they do business, and how they manage their sustainability impacts (GRI and IOE, 2014). There are two values of sustainability reporting for VOE and SMEs business (GRI, 2014). The first value is value of internal changes (internal benefits) and the next value is value of recognition (external benefits). The parts of value of internal changes are vision and strategy, management systems, strength and weakness, and employee motivation. The value of recognition divided into reputation and trust, attracting fund, stakeholder engagement, and competitive advantage.

1. Develop vision and strategy on sustainability business

The sustainability reporting process support the VOE and SMEs to identify the vision and strategy on sustainability issues. Also support the VOE and SMEs business to operate in more sustainable manner.

2. Improve management systems

The important benefit of the sustainability reporting process is allow VOE and SMEs management track progress or highlight sections needing some improvement. This process help VOE and SMEs management to identify areas where they could be doing better, example waste management, relations with stakeholders, supply chain management, and customer relationship management.

3. Identification of strength and weakness

The sustainability reporting process can help and support VOE and SMEs management to evaluate potentially damage in their business. Improve their concept about risk management and grab opportunities before the competitors.

4. Increase the employee motivation

The sustainability reporting process shows that the VOE and SMEs management is not only discuss or talking about sustainability issues, but also practice their business in real sustainability context, especially in social issues. This step will increase the trust between management and their employees. The result is the employees will contribute more than before and support the strategic objectives of VOE and SMEs business.

5. Increase reputation and trust from stakeholders

The sustainability reporting process help the VOE and SMEs management to maintain their relations with company's key stakeholders. Disclose the financial, social, and environmental information can create trust and respect from stakeholders. Company's key stakeholders are influenced by the reputation and trust the management have earned.

6. Attracting fund

Lending institutions (banking industry) and investors increasingly have high concern about company's performance in different aspects of sustainability issues when

* Corresponding author. Putu Sukma Kurniawan is a Lecturer at the Faculty of Economics, Universitas Pendidikan Ganesha, Indonesia, e-mail: putusukma1989@gmail.com 
evaluating companies, such as good governance, ethical values on organization, social activities, and environmental actions.

7. Increase the dialogue with stakeholder (stakeholder engagement)

This is the main function of sustainability reporting process. Sustainability reporting process is an important tool to reach transparency and disclose sustainability performance to VOE and SMEs stakeholders. The reporting process can create relationship between management and their stakeholders. Management can achieve some advices from their stakeholders about the business process and identify business opportunities.

8. Achieve competitive advantage

Sustainability reporting is still not common practice across all regions and sectors, especially for SMEs. The first user of sustainability reporting can be identified as a "leader in sustainability". This is especially important because an increasing number of larger companies screen potential and current suppliers for their economic, social, and environmental performance and the impact this may have on their own supply chain.

\section{Prior Research about Sustainability Issues and Sustainability Reporting on VOE and SMEs}

This article is based on the papers of Castka et al. (2004) who were investigating the implementation of corporate social responsibility (CSR) conducted by SMEs in the UK. Castka et al. (2004) argue that CSR is a concept to run organizations profitably yet in a socially and environmentally responsible way in order to reach business sustainability and stakeholder's satisfaction. This article is also based on research by Arena and Azzone (2012), which discusses the theoretical approaches to sustainability reporting weigh SMEs with the SMEs characteristics. The approach proposed by Arena and Azzone (2012) to minimize the problems faced by SMEs in making sustainability reporting. Borga et al. (2009) tried to develop a guideline for assessing the sustainability process in SMEs. Some items guidelines developed by Borga et al. (2009) is in accordance with the SMEs business environment and the characteristics of SMEs. Bos-Brouwers (2010) examined the sustainability report on SMEs by using case studies on the meuble companies. Longo et al. (2005) contribute to give a clear understanding of the social commitments undertaken by SMEs businesses. In addition Longo et al. (2005) also analyzed the characteristics of CSR by SMEs and identify CSR activities undertaken to support the creation of social value of the SMEs business. Wiesner et al. (2017) develop a model for managing change toward environmental sustainability within SMEs by investigating the main environmental sustainability change and the findings provide and empirically environmental sustainability model. Caputo et al. (2017) develop of a new conceptual model to highlight the factors driving SMEs towards effective introduction of sustainability management tools and introducing a sustainable report.

\section{Research Method}

This research design is a case study and a qualitative descriptive study. A case study approach is appropriate when a researcher needs to conduct a holistic and in-depth analysis of a complex phenomenon (Caputo et al., 2017). In the qualitative descriptive study, the research 
aims to reach current information related to the variables studied. This research was conducted at the village-owned enterprises in Tajun village. In this study, we made some interviews and observations on village-owned enterprise (VOE) BUMDes Amertha Mandala Giri in Tajun village, Buleleng, Bali and also some SMEs in Tajun village. There are some reasons this study use BUMDes Amertha Mandala Giri and some SMEs in Tajun village as an object of research. First, operational activities of this VOE and SMEs directly related to their community and the environment. The impact from VOE and SMEs activities divided into three categories such as economic value impact, social community impact, and environmental impact. Second, BUMDes Amertha Mandala Giri have four business units. The business units are Village Facility Management Unit, Integrated Waste Management Unit, Saving and Loans Unit, and Market Management Unit. Based on this fact, BUMDes Amertha Mandala Giri has a complex business structure. It's very interesting to examine BUMDes Amertha Mandala Giri for the Integrated Waste Management Unit in which the unit have an integrated waste processing and business activity of the unit produces some external impacts, particularly in social and environmental impacts.

This research used some methods to collect the data. The first is semi-structured interview. This study used the semi-structured interview because of its high degree of flexibility (Caputo et al., 2017; Qu and Dumay, 2011). Interviews were conducted to VOE and SMEs management, the government of Tajun village, and the communities in Tajun village. Interviews were conducted by purposive sampling, that is, people who were interviewed in accordance with the purposes and objectives of researchers. In addition, snowball sampling technique was also used to obtain the relevant informants from key informants. The second method is observation. The observation method was used to understand about the (1) internal business of VOE and SMEs, (2) the level of implementation sustainability context in their business, (3) the criteria and characteristic of their stakeholders, and (4) the materiality information that related with their business. The last method is document analysis. The researcher was collected some documents from VOE and SMEs office, such as photos, standard and operational procedures, and other documents.

There are four processes in this research. The first is initial research and including with the data collection process. The main process in this research is the process to create sustainability reporting model and the implementation of the sustainability reporting model. This research used literature research or literature method in the process of create sustainability reporting model and the implementation of the sustainability reporting model. This research used articles and papers that related with the sustainability reporting topic as the reference to build the model. The design of this study, namely

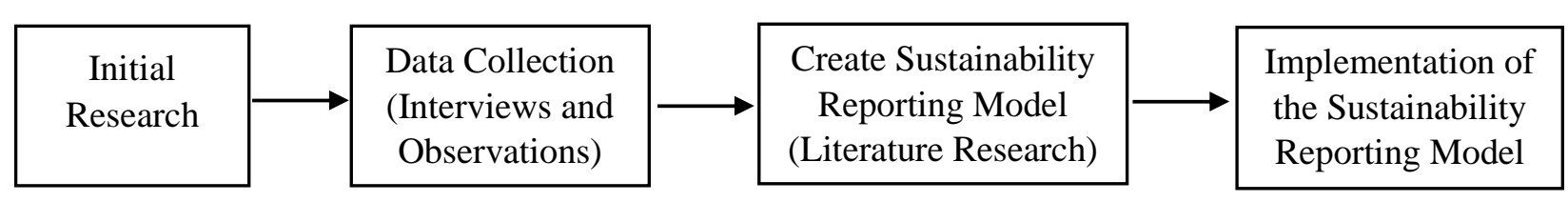

Pic. 1. The process of research

This research used GRI G4 Standard as a main reference to create sustainability reporting concept and model for VOE and SMEs. GRI G4 Standard was developed by GRI (Global

* Corresponding author. Putu Sukma Kurniawan is a Lecturer at the Faculty of Economics, Universitas Pendidikan Ganesha, Indonesia, e-mail: putusukma1989@gmail.com 
Reporting Initiative). GRI G4 standard used in the implementation model because it is a basic standard in sustainability reporting and the points on the standard GRI G4 has reflected the economic value, social value, and environmental value in accordance with the concept of sustainability. This study also used the guideline compiled by Borga et al. (2009) at the phase of implementation of the sustainability reporting model. Borga et al. (2009) propose the new guidelines that address the content of sustainability report, specially adjusted for the characteristics of small and medium enterprises (SMEs).

\section{Result and Discussion}

\section{Implementation of GRI Guideline in Sustainability Reporting for VOE and SMEs}

The author argues that the concept of sustainability is not only applied by the company in a great industry but also VOE and SMEs can run its business activity based on the concept of sustainability. GRI (2014) and NCSR (2017) provides a model of sustainability reporting process using the standard GRI G4. In general, the process model consists of five stages: (1) prepare, (2) connect, (3) define, (4) monitor, and (5) report. Prepare stage is an early stage in the process of sustainability reporting. This phase is used to determine the form of the report and choose the approach that will be used in the sustainability report. In this phase of the VOE and SMEs businesses can determine how the form and content of the report later. At this stage it may also set up a team that will draw up a plan of sustainability reporting. The second stage is connect stage. At this stage, VOE and SMEs management must be able to identify which stakeholders are most in need of a sustainability report. In this context, the VOE and SMEs management will present the information required by the stakeholders. The next step is define which at this stage VOE and SMEs management should be able to assess which aspects that are material and should be presented in their sustainability report. Materiality level information can be determined also from the information which is most important and most needed by the company's stakeholders. The next stage is the monitor where at this stage VOE and SMEs management must assess whether the draft report is in accordance with the principles of reporting. At this stage also can be made lists of information that will be included in sustainability reports. The last is a report stage which is the stage of issuing or publishing a sustainability report. In part of this stage, the VOE and SMEs management can perform a communication with stakeholders through a discussion to see the information presented. It also can be a form of evaluation for the improvement of the sustainability report in the following year. 


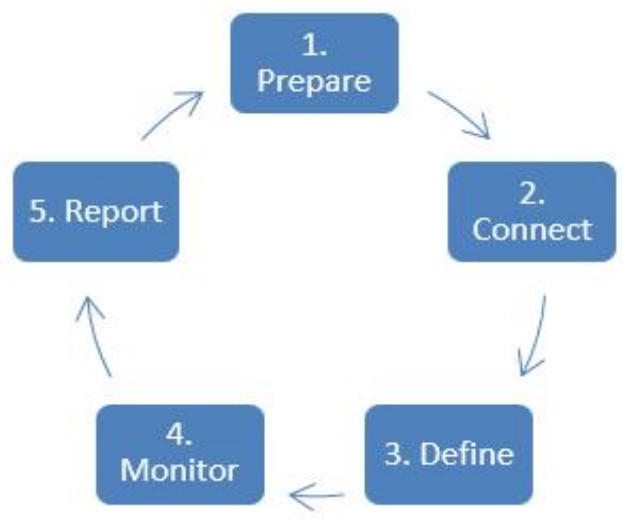

Pic. 2. The process of sustainability reporting

Source: GRI (2014) and NCSR (2017)

\section{Sustainability Reporting Model for VOE and SMEs}

The implementation of sustainability reporting model on VOE and SMEs in this article is based on a sustainability reporting process established by the GRI (2014) and NCSR (2017). Research from Russo and Tencati (2009) confirms that SMEs (and also VOE) sustainability strategies are generally informal, while large company's sustainability strategies have a higher degree of integration within corporate strategy. This is an advantage for VOE and SMEs management in the context of adopted sustainability reporting in their business. Based on GRI (2014) and NCSR (2017) there are five stages on sustainability reporting model for VOE and SMEs and each stage contains the activities.

1. Prepare stage

There are two activities in this stage. The first is determine the approach of reporting. In general, in the preparation of sustainability reports, there are two approaches, namely the "core" and "comprehensive". A "core" means that not all the points in the standard GRI G4 will be presented in the sustainability report, while a "comprehensive," meaning that all points in the standard GRI G4 will be presented in the sustainability report. The determination of this approach is largely determined by the company's ability to meet the standards of GRI G4. In this context we must understand that the level of complexity of SMEs are not as high as the large companies in the industry. Thus in the preparation of sustainability reports our SMEs we can use a "core" approach. The second activity is determine the disclose indicator. When the selected approach is "core" then at least there is one aspect that must be disclosed in the disclosure of general standards and disclosure of specific standards. For example, in the disclosure of general standards, SMEs management can disclose information about the SMEs business strategy, organization profiles, which are considered important stakeholders and reporting principles. While the disclosure of specific standards, SMEs management can disclose at least one indicator of each aspect contained in each category. There are three categories in the disclosure of specific standards, namely economic category that includes four aspects, environmental categories covering twelve aspects, and social category that includes thirty aspects. GRI (2014) gives some other activities in this stage, likes (1) ensure that the top management are committed to

* Corresponding author. Putu Sukma Kurniawan is a Lecturer at the Faculty of Economics, Universitas Pendidikan Ganesha, Indonesia, e-mail: putusukma1989@gmail.com 
this process, (2) identify an initial lists of sustainability topics that are potentially to disclose, and (3) make the company's business goals and the sustainability context in which company's operate and list the economic, social, and environmental impacts which might be most important. At this stage, VOE and SMEs management also provide a clear picture of how the organization creates value and explain about operations and activities.

2. Connect stage

There is one phase in this stage. The phase is identify the stakeholder's who influence the VOE and SMEs business. At this phase, the VOE and SME's management must identify which stakeholder's who have a high influence or high impact on the business activities of VOE and SMEs. Stakeholder's can be defined as the parties relating to VOE and SMEs and could be affected by the business activities of VOE and SMEs. Evans and Sawyer (2010) says that local communities are the most influential stakeholder's and have a high impact from the VOE and SMEs business activities. VOE and SMEs management should also identify the others stakeholder's for example the government, the supplier, and the banking industry. The initial list of potentially relevant information's (at the early stage) can be useful to identify the key stakeholders. (GRI 2014) gives some added activities in this stages. The first is VOE and SMEs management must consider the best ways to communicate with the key stakeholders. When preparing stakeholder engagement there are two important factor: (1) the objective of the consultation and (2) the format of the consultation. The second is the outcome of company's stakeholder engagement is a list of the sustainability topics that the stakeholders consider important.

3. Define stage

There is one phase in this stage. The phase is determine the aspect of materiality (materiality level) or determining the materiality aspects. Materiality level is how high the impact generated by the business activities of VOE and SMEs in particular to VOE and SMEs stakeholders. If business activity of VOE and SMEs have a high impact (having a high materiality), then the business activity and the impact should be presented as the information in the VOE and SMEs sustainability report. One way to determine the materiality aspect is to make a list or a table that contains a company's business activity and impacts (positive and negative impacts) and also the influential stakeholders of VOE and SMEs. Some indicators that may be material to the business environment of VOE and SMEs, for example, responsibility for the product, waste management, energy and water usage, and employee benefits. Determining materiality aspects can also be based on the priorities of the stakeholders.

4. Monitoring stage

There is one phase in this stage. The phase is make a list of information to be disclosed in the sustainability report. At this stage, VOE and SMEs management can create a list that contains any information that will be disclosed in their sustainability report. Of course, this information is material information and needed by their stakeholders. At this stage, the VOE and SMEs management should concern about their stakeholders dialogue. Medel et al. (2011) argue that stakeholder dialogue is an important element to reach the corporate sustainability and establishing a feedback among business 
sustainability based on internal and external stakeholders. GRI (2014) argue that the main objective during this phase is to collect and analyze the information in order to build the content of sustainability report.

5. Reporting stage

This is the last stage of sustainability reporting model for VOE and SMEs. There is one phase of this stage. The phase is publish the VOE and SMEs sustainability report. GRI (2014) argue that the main objective in this phase is to complete the sustainability report and release it to public. At this stage, VOE and SMEs management can publish a sustainability report to their stakeholders. At this stage, the communication can be built between VOE and SMEs management with their stakeholders, such as government and local communities. The VOE and SMEs management can assess the effectiveness of the information presented in the sustainability report. At this stage, VOE and SMEs management can ask for opinions and suggestions from their stakeholders. Comments and suggestions can be used as an evaluation for the preparation of sustainability reports in the next year. In the following year, sustainability report of VOE and SMEs still use a "core" approach but the information presented can be more comprehensive and specific in accordance with the opinions and suggestions of VOE and SMEs stakeholders. The VOE and SMEs management should consider two things in this stage to complete the reporting process (GRI, 2014). The first is compile the necessary information for each of the data points that are needed to address the GRI G4 Standard Disclosures. The second is make sure that the reports gives a complete picture and uses concise text and also make sure that there are clear and agreed deadline dates for feedback and the final sign off.

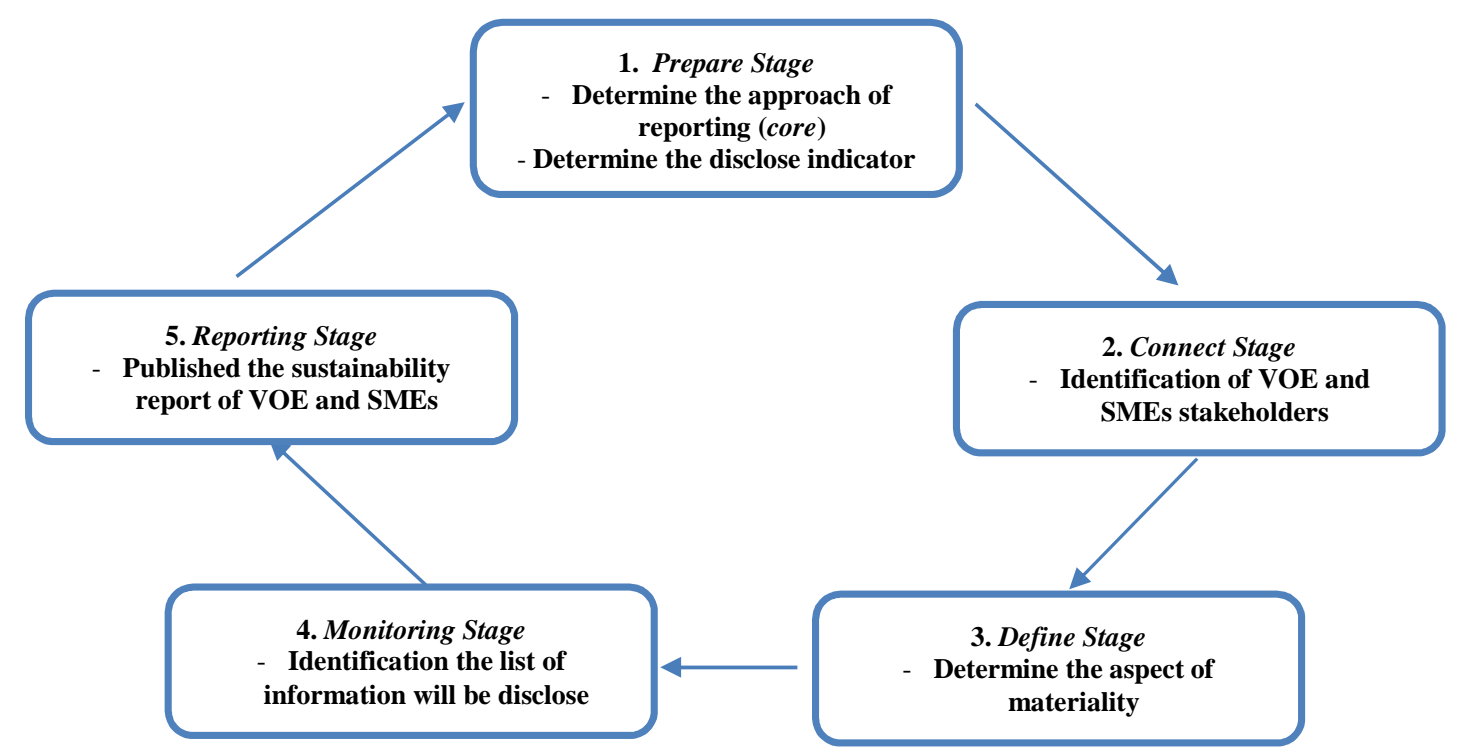

Pic. 3. Sustainability reporting model on VOE and SMEs

\section{Implementation of Sustainability Reporting Model on VOE and SMEs}

The main purpose of this paper is to implement our sustainability reporting model on VOE and SMEs business. This section discuss how to implement our sustainability reporting

* Corresponding author. Putu Sukma Kurniawan is a Lecturer at the Faculty of Economics, Universitas Pendidikan Ganesha, Indonesia, e-mail: putusukma1989@gmail.com 
model on BUMDes Amertha Mandala Giri and SMEs in Tajun village. We use some semistructured interviews and observations to collect initial data at this section. There are five stages in this section and at the last stage (monitoring stage and reporting stage) we uses guideline compiled by Borga et al. (2009) as a reference to determine the information that should be disclosed by VOE and SMEs management.

1. Implementation of prepare stage

There are two phases of this stage. The first is determine the approach of reporting. The approach used in this research is "core" approach. This approach means that BUMDes Amertha Mandala Giri and SMEs only disclose partial information in their sustainability report. The "core" approach determined based on the characteristics of BUMDes Amertha Mandala Giri and SMEs. The next phase is determine the disclose indicator. At this stage, management of BUMDes Amertha Mandala Giri and SMEs can choose at least one indicator of each aspects that they must be disclosed. Based on GRI G4, management should disclose general standards and specific standards. To simplify the implementation of this model on BUMDes Amertha Mandala Giri and SMEs, this study prefers to use Borga's guideline as a reference to create information list should be disclosed.

2. Implementation of connect stage

The purposes of this stage is to identify the stakeholders of BUMDes Amertha Mandala Giri and SMEs. This process of identifying stakeholders is important to know which stakeholders are affected by BUMDes Amertha Mandala Giri and SMes business activities. BUMDes Amertha Mandala Giri have four units (Village Facility Management Unit, Integrated Waste Management Unit, Saving and Loans Unit, and Market Management Unit). Based on this fact, this study can estimated the stakeholders are affected caused by their business activities. The stakeholders are divided into two categories, internal stakeholders and external stakeholders. The internal stakeholders of BUMDEs Amertha Mandala Giri and SMEs are employees and the village government (as the owner of BUMDes). The external stakeholders of BUMDes Amertha Manda Giri and SMEs are local government, village communities (also as customers), the suppliers, and the banking industry.

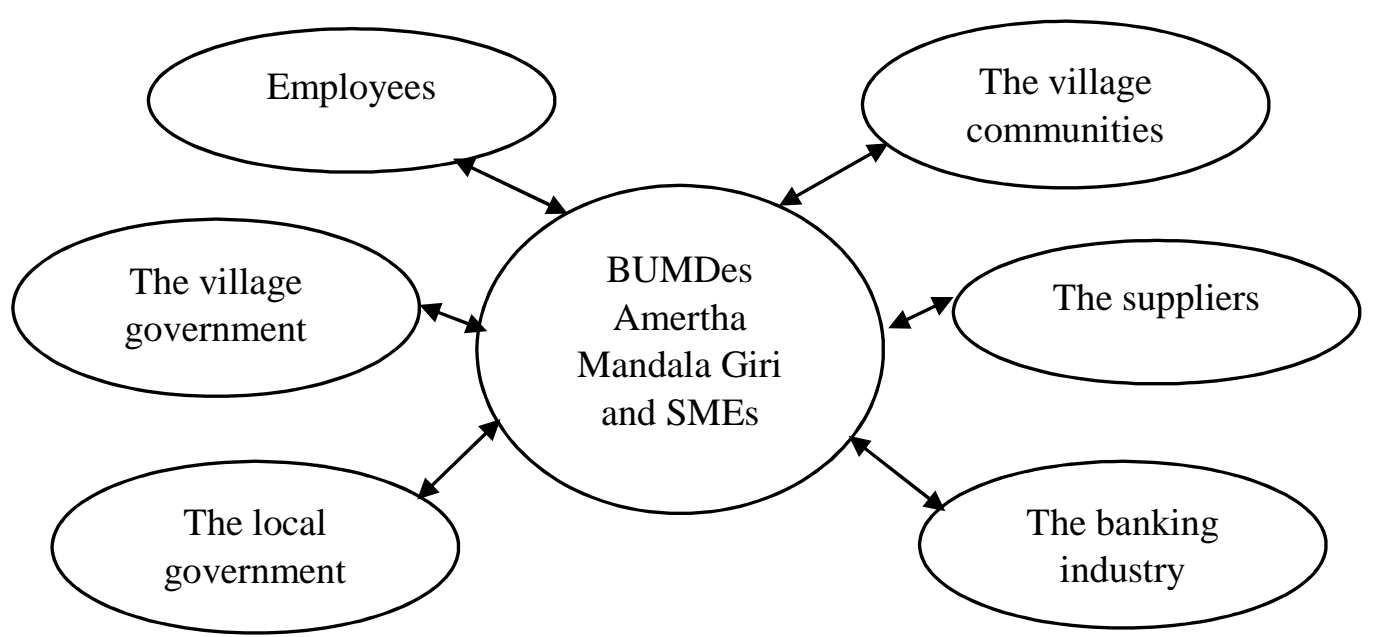

Pic. 4. The stakeholders of BUMDes Amertha Mandala Giri and SMEs 
3. Implementation of define stage

The phase in this stage is determine the aspect of materiality. The aspect of materiality determined based on the list of stakeholders. The materiality of information is determined by stakeholders BUMDes Amertha Mandala Giri and SMEs. Each stakeholder has a different kind of material information with the other stakeholders. At this stage, the management of BUMDEs Amertha Mandala Giri and SMEs will create a list of information that is material to each stakeholder. This list will also contain information materiality levels. The level of materiality of information consists of high level, medium level and low level. The level of materiality information in this research depends on management perspectives and very subjective. Materiality levels indicate how much information influence the stakeholder's decision-making process. Caputo et al. (2017) also create a matrix of materiality to identify the important information. Caputo et al. (2017) were collected the data using a questionnaire administered to stakeholders.

Table 1. Map of materiality in BUMDes Amertha Mandala Giri and SMEs

\begin{tabular}{|c|c|c|}
\hline Stakeholder & Important Information & The Level of Materiality \\
\hline Employees & $\begin{array}{l}\text { - Health and safety } \\
\text { - Financial performance } \\
\text { - Training } \\
\text { - Employees benefit } \\
\text { - Social and environmental } \\
\text { impacts }\end{array}$ & $\begin{array}{l}\text { - High } \\
\text { - High } \\
\text { - High } \\
\text {-High } \\
\text {-Medium }\end{array}$ \\
\hline The Village Government & $\begin{array}{l}\text { - Mission and values of the } \\
\text { organization } \\
\text { - Financial performance } \\
\text { - Social and environmental } \\
\text { impacts }\end{array}$ & $\begin{array}{l}\text {-High } \\
\text {-High } \\
\text {-High }\end{array}$ \\
\hline The Local Government & $\begin{array}{l}\text { - Mission and values of the } \\
\text { organization } \\
\text { - Financial performance } \\
\text { - Social and environmental } \\
\text { impacts }\end{array}$ & $\begin{array}{l}\text {-High } \\
\text {-High } \\
\text {-High }\end{array}$ \\
\hline $\begin{array}{l}\text { The Village Communities } \\
\text { (Also as customers) }\end{array}$ & $\begin{array}{l}\text { - Social and environmental } \\
\text { impacts } \\
\text { - Safety and quality of } \\
\text { products and services }\end{array}$ & $\begin{array}{l}\text {-High } \\
\text {-High }\end{array}$ \\
\hline The Suppliers & $\begin{array}{l}\text { - Financial performance } \\
\text { - Social and environmental } \\
\text { impacts }\end{array}$ & $\begin{array}{l}\text {-High } \\
\text {-Low }\end{array}$ \\
\hline The Banking Industry & $\begin{array}{l}\text { - Financial performance } \\
\text { (sales, profit/loss) } \\
\text { - Social and environmental } \\
\text { impacts }\end{array}$ & $\begin{array}{l}\text {-High } \\
\text {-Low }\end{array}$ \\
\hline
\end{tabular}

* Corresponding author. Putu Sukma Kurniawan is a Lecturer at the Faculty of Economics, Universitas Pendidikan Ganesha, Indonesia, e-mail: putusukma1989@gmail.com 
4. Implementation of monitoring stage

The phase of this stage is identification the list of information will be disclose. Borga et al. (2009) proposed the sustainability report guideline for small and medium enterprises. The proposed guideline are divided into four main sections such as company identity, economic impact, social impact, and environmental impact. Management of BUMDEs Amertha Mandala Giri and SMEs suggested to use this guideline to identify the list of information.

\section{Section 1 - Company Identity}

\begin{tabular}{|c|c|}
\hline Company Structure & $\begin{array}{l}\text { - General information } \\
\text { - Brief history } \\
\text { - Company identity (including products } \\
\text { or services } \\
\text { - Structure of the organization } \\
\text { - Main reference markets }\end{array}$ \\
\hline Values and Social Commitment & $\begin{array}{l}\text { - Mission and organization values } \\
\text { - Certifications, recognitions, and } \\
\text { adopted codes } \\
\text { - Role in the society and future } \\
\text { commitments }\end{array}$ \\
\hline Introduction of Sustainability Report & $\begin{array}{l}\text { - Report purpose } \\
\text { - Reporting period } \\
\text { - Guidelines or principles followed in } \\
\text { the reporting } \\
\text { - Previous edition of the report and } \\
\text { significant changes (for second report } \\
\text { or later) } \\
\text { - Contact person for the report }\end{array}$ \\
\hline
\end{tabular}

Section 2 - Economic Impact

\begin{tabular}{|c|c|}
\hline Economic Performance Indicators & $\begin{array}{l}\text { - Enterprise's resources (shareholder's } \\
\text { equity, working capital, and assets) } \\
\text { - Financial review (turnover and } \\
\text { profit/loss) }\end{array}$ \\
\hline Impact & $\begin{array}{l}\text { - Purchases: total value } \\
\text { - Investments: typology, amount and } \\
\text { objectives } \\
\text { - Value added: calculation and allocation }\end{array}$ \\
\hline
\end{tabular}

\section{Section 3 - Social Impact}

\begin{tabular}{|c|l|}
\hline $\begin{array}{c}\text { Identification and Selection of Major } \\
\text { Stakeholders }\end{array}$ & $\begin{array}{l}\text { - Management of BUMDes Amertha } \\
\text { Mandala Giri and SMEs should } \\
\text { identifying the major stakeholders }\end{array}$ \\
\hline & $\begin{array}{l}\text { - Number of employees } \\
\text { Personnel selection and management } \\
\text { policies }\end{array}$ \\
\hline
\end{tabular}




\begin{tabular}{|c|c|}
\hline Relations with Employees & $\begin{array}{l}\text { - Worker's average stay in the BUMDEs } \\
\text { and SMEs } \\
\text { - Employees satisfaction } \\
\text { - Health and safety in workplace } \\
\text { - Equality of treatment } \\
\text { - Training } \\
\text { - Employees benefits } \\
\text { - Future plans and upcoming } \\
\text { commitments }\end{array}$ \\
\hline Relations with Customers & $\begin{array}{l}\text { - General description } \\
\text { - Relationship towards customers and } \\
\text { level of involvement } \\
\text { - Customers satisfaction } \\
\text { - Product or service safety and quality } \\
\text { information } \\
\text { - Privacy protection and management of } \\
\text { customers data } \\
\text { - Future plans and upcoming } \\
\text { commitments }\end{array}$ \\
\hline Relations with Suppliers & $\begin{array}{l}\text { - General description } \\
\text { - Policy for supplier selection and control } \\
\text { - Collaboration with suppliers } \\
\text { - Future plans and upcoming } \\
\text { commitments }\end{array}$ \\
\hline $\begin{array}{l}\text { Relations with the Local Community } \\
\text { (Village Communities) }\end{array}$ & $\begin{array}{l}\text { - Contribution in supporting local } \\
\text { community } \\
\text { - 'Economic regeneration' activities } \\
\text { - Description of training events towards } \\
\text { local community } \\
\text { - Future plans and upcoming } \\
\text { commitments }\end{array}$ \\
\hline $\begin{array}{l}\text { Relations with Public Authorities (Local } \\
\text { Government and Banking Industry) }\end{array}$ & $\begin{array}{l}\text { - Collaboration program with public } \\
\text { authorities } \\
\text { - Future plans and upcoming } \\
\text { commitments }\end{array}$ \\
\hline
\end{tabular}

\section{Section 4 - Environmental Impact}

\begin{tabular}{|c|l|}
\hline \multirow{4}{*}{ Environmental Policy } & $\begin{array}{l}\text { - Environmental critical level } \\
\text { - Environmental policy and program } \\
\text { - Certification and/or adopted standards and } \\
\text { existing control }\end{array}$ \\
\hline & $\begin{array}{l}\text { - Amount of used raw materials } \\
\text { - Amount of imperfect goods per type of } \\
\text { Raw Material Use }\end{array}$ \\
\hline
\end{tabular}

* Corresponding author. Putu Sukma Kurniawan is a Lecturer at the Faculty of Economics, Universitas Pendidikan Ganesha, Indonesia, e-mail: putusukma1989@gmail.com 


\begin{tabular}{|c|c|}
\hline & $\begin{array}{l}\text { - Criteria for minimization of } \\
\text { environmental impact when designing } \\
\text { products and choosing materials } \\
\text { - Environmental criteria for supplier } \\
\text { selection }\end{array}$ \\
\hline Energy Use & $\begin{array}{l}\text { - Total amount of consumed energy } \\
\text { - Existing policies/instruments for } \\
\text { minimizing energy consumption }\end{array}$ \\
\hline Water Use and Wastewater & $\begin{array}{l}\text { - Total amount of consumed water } \\
\text { - Existing policies/instruments } \\
\text { minimizing water consumption }\end{array}$ \\
\hline Air Emissions & $\begin{array}{l}\text { - List of critical emissions } \\
\text { - Existing policies/instruments } \\
\text { minimizing dangerous emissions }\end{array}$ \\
\hline Waste Management & $\begin{array}{l}\text { - List of dangerous wastes and their disposal } \\
\text { - Existing policies for recycling and } \\
\text { minimizing wastes } \\
\text { - Existing policies for reducing and re-using } \\
\text { packaging wastes }\end{array}$ \\
\hline Environmental Impact & $\begin{array}{l}\text { - Evaluation of environmental impact } \\
\text { - Plans and upcoming commitments for } \\
\text { environmental protection }\end{array}$ \\
\hline
\end{tabular}

Source: Borga et al. (2009)

5. Implementation of reporting stage

The main function in this stage is to create the relations between VOE and SMEs management (management of BUMDEs Amertha Mandala Giri and SMEs) and their stakeholders through sustainability report. The point in this stage is sustainability report should be credible. Sustainability report should be balanced and the information should be accurate and reliable (GRI and IOE, 2014). At this stage, the management of VOE and SMEs publish their sustainability report. The content of the sustainability report is based on the information table at step 4. This stage is the final stage of the sustainability reporting process at VOE and SMEs. Another function in this stage is bridge the gap between management of VOE and SMEs and their stakeholders. The flow of information (financial information and non-financial information) will increase from management to stakeholders through their sustainability reports. It's important to build legitimacy and confidence between management and stakeholders. One of the most important parts of this stage is feedback from the stakeholders. Feedback from stakeholders can contain some advices about the sustainability report. This feedback is important to improve the quality of the sustainability report. This cycle provides some benefits to the management of BUMDes Amertha Mandala Giri and SMEs and the company's stakeholders. There are some benefits for management of BUMDes Amertha Mandala Giri and SMEs such as increasing the quality of internal business and improving the quality of sustainability report. The benefit for the stakeholders of 
BUMDes Amertha Mandala Giri and SMEs are increasing the quality of decision making process and creating a strong relationship with management.

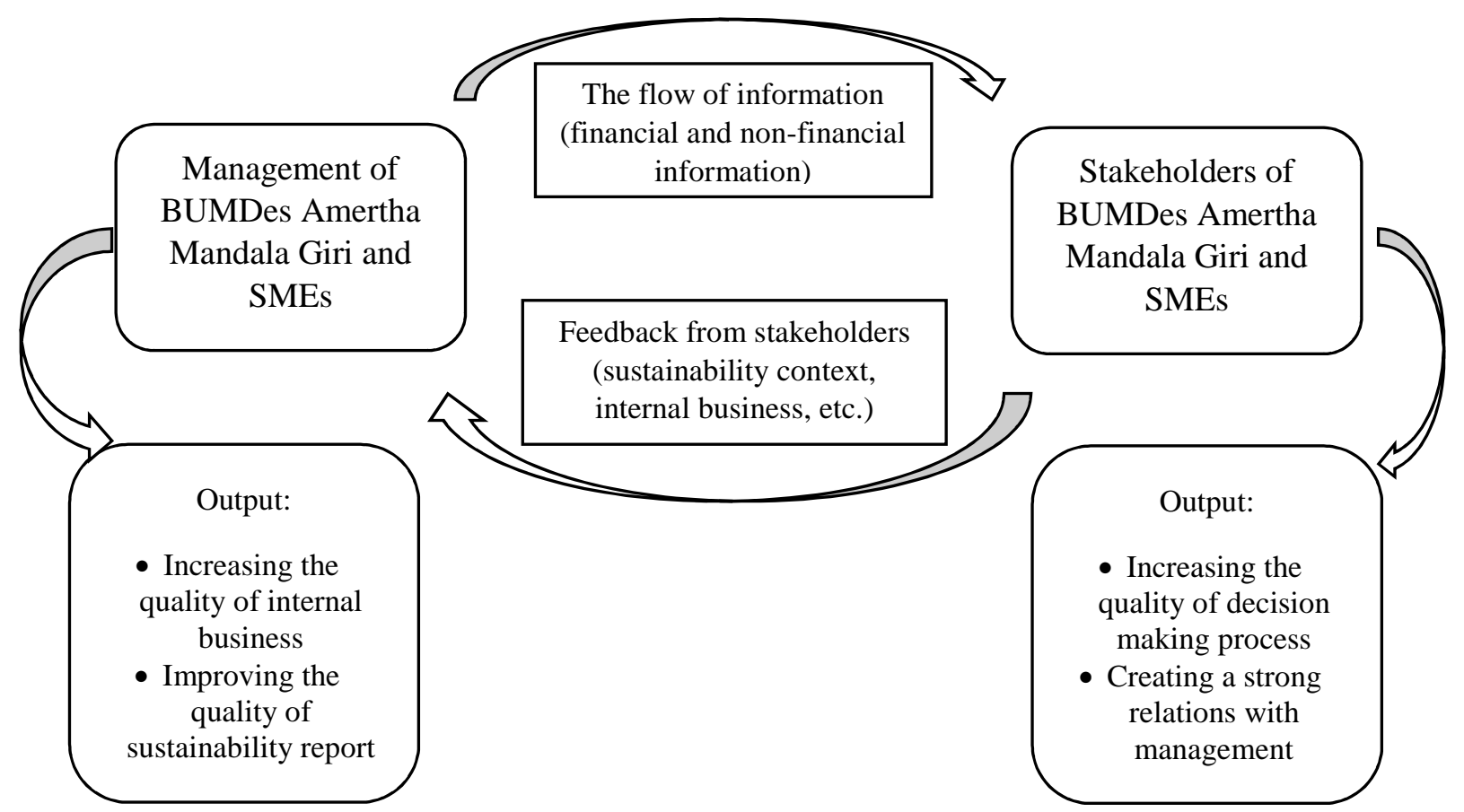

Pic. 5. The implementation of reporting stage

\section{Conclusion}

The conclusion is sustainability reporting has an important role in VOE and SMEs internal business. This concept of reporting bring our VOE and SMEs into the next level and more capability before this era. The concept of sustainability reporting also transform traditional VOE and SMEs into a modern VOE and SMEs. This result indicated that VOE and SMEs can more contribute than other related business in sustainability context. This sustainability reporting model can help VOE and SMEs management to create their sustainability report. VOE and SMEs should showed that they have a good opportunity and capability to adopted sustainability reporting. We need more effort to promote and campaign sustainability reporting in our business system. We believe adopted sustainability reporting model is important for VOE and SMEs internal business. Making their internal business more transparency in the context of delivering information, especially financial and non-financial information. Massa et al. (2015) found that report about sustainability context is important to enhance the sustainable development business and awareness, consider long-term planning, support strategy-making based on the sustainability context, and enhance the reputation.

The VOE and SMEs management must realize that they are also the part of business systems. VOE and SMEs have a crucial role to play in creating a sustainable future (GRI and IOE, 2014). Based on this fact, they must support the implementation of sustainability reporting. Caputo et al. (2017) identified three internal forces that drove SMEs to implement and disclose sustainability report such as the role of stakeholders in influencing corporate strategies, the main role played by the CEO in committing the company to start disclose * Corresponding author. Putu Sukma Kurniawan is a Lecturer at the Faculty of Economics, Universitas Pendidikan Ganesha, Indonesia, e-mail: putusukma1989@gmail.com 
sustainability report, and infrastructure to measure and interpret sustainability data. If all of companies management understand about the important of sustainability reporting for their business, so it can be easier to implement sustainability reporting in our business systems. Based on this model, we also can create a green business strategies and concept for VOE and SMEs business.

\section{References}

Association of Chartered Certified Accountants (ACCA). 2010. Small Business: A Global Agenda. London: ACCA.

Arena, M., \& Azzone, G. (2012). A process-based operational framework for sustainability reporting in SMEs. Journal of Small Business and Enterprise Development, 19(4), 669-686.

Battaglia, M., Bianchi, L., Frey, M., \& Iraldo, F. (2010). An innovative model to promote CSR among SMEs operating in industrial clusters: Evidence from an EU project. Corporate Social Responsibility and Environmental Management, 17(3), 133-141.

Borga, F., Citterio, A., Noci, G., \& Pizzurno, E. (2009). Sustainability report in small enterprises: Case studies in Italian furniture companies. Business Strategy and the Environment, 18(3), 162-176.

Bos Brouwers, H. E. J. (2010). Corporate sustainability and innovation in SMEs: Evidence of themes and activities in practice. Business Strategy and the Environment, 19(7), 417-435.

Caputo, F., Veltri, S., \& Venturelli, A. (2017). A conceptual model of forces driving the introduction of a sustainability report in SMEs: Evidence from a case study. International Business Research, 10 (5), 39-50

Castka, P., Balzarova, M. A., Bamber, C. J., \& Sharp, J. M. (2004). How can SMEs effectively implement the CSR agenda? A UK case study perspective. Corporate Social Responsibility and Environmental Management, 11(3), 140-149.

European Commission. 2001. Promoting a European Framework for Corporate Social Responsibility, Green Paper. European Commission, Directorate-General for Employment and Social Affairs: Luxembourg.

Evans, N., \& Sawyer, J. (2010). CSR and stakeholders of small businesses in regional South Australia. Social Responsibility Journal, 6(3), 433-451.

Global Reporting Initiative. (2014). Ready to Report? Introducing Sustainability Reporting for SMEs. Amsterdam: GRI.

Global Reporting Initiative and International Organisation of Employers. 2014. Small Business Big Impact: SME Sustainability Reporting From Vision to Action. Amsterdam: GRI.

Jenkins, H. (2008). A 'business opportunity'model of corporate social responsibility for small and medium sized enterprises. Business Ethics: A European Review, 18(1), 21-36.

Johnson, M. P., \& Schaltegger, S. (2016). Two decades of sustainability management tools for SMEs: how far have we come? Journal of Small Business Management, 54(2), 481-505.

Kocmanová, A., Dočekalová, M., Němeček, P., \& Šimberová, I. (2011, July). Sustainability: Environmental, social and corporate governance performance in Czech SMEs. In The 15th World Multi-Conference on Systemics, Cybernetics and Informatics (pp. 94-99). 
Lawrence, S.R., Collins, E., Pavlovich, K., \& Arunachalam, M. (2006). Sustainability practices of SMEs: The Case of NZ. Business Strategy and the Environment, 15, 242-257.

Longo, M., Mura, M., \& Bonoli, A. (2005). Corporate social responsibility and corporate performance: The case of Italian SMEs. Corporate Governance: The International Journal of Business in Society, 5(4), 28-42.

Massa, L., Farneti, F., \& Scappini, B. (2015). Developing a sustainability report in a small to medium enterprise: process and consequences. Meditari Accountancy Research, 23(1), 6291.

Medel, F., Garcia, L., Enriquez, S., \& Anido, M. (2011). Reporting models for corporate sustainability in SMEs. Information Technologies in Environmental Engineering, 3, 407418.

National Center for Sustainability Reporting (NCSR). 2017. GRI G4 Certified Training Course GRI Sustainability Reporting Process. Malang: NCSR.

Perrini, F. (2006). SMEs and CSR theory: Evidence and implications from an Italian perspective. Journal of Business Ethics, 67(3), 305-316.

Qu, S. Q. \& Dumay, J. (2011). The qualitative research interview. Qualitative Research Accounting and Management, 8(3), 238-264. https://doi.org/10.1108/11766091111162070

Russo, A. \& Tencati, A. (2009). Formal vs informal CSR strategies: The Case of Italian SMEs. Journal of Business Ethics, 85 (2).

Wiesner, R., Chadee, D., \& Best, P. (2017). Managing Change Toward Environmental Sustainability: A Conceptual Model in Small and Medium Enterprises. Organization \& Environment, https://doi.org/10.1177/1086026616689292

* Corresponding author. Putu Sukma Kurniawan is a Lecturer at the Faculty of Economics, Universitas Pendidikan Ganesha, Indonesia, e-mail: putusukma1989@gmail.com 
